\title{
REGULARARTICLE \\ GENETIC VARIABILITY, CORRELATION AND CLUSTER ANALYSIS IN ELITE LINES OF RICE
}

\author{
TOUHEED IQBAL ${ }^{1}$, IQBAL HUSSAIN ${ }^{2}$, NAZIR AHMAD ${ }^{2}$, MUHAMMAD NAUMAN3, MUJAHID ALI3, \\ SAAD SAEED3, MUHAMMAD ZIA3, FAWAD ALI4
}

\author{
${ }^{1}$ Agricultural Research Institute, Dera Ismail Khan, Khyber Pakhtunkhwa, Pakistan \\ ${ }^{2}$ Sichuan Agricultural University, Chengdu, China \\ 3The University of Agriculture, Peshawar, Pakistan \\ 4Department of Plant Sciences, Quaid-e-Azam University, Islamabad, Pakistan
}

\begin{abstract}
Development of rice cultivars with appreciative performance is one of the prime objectives of rice breeding programs. In this regard, the current experiment was conducted during 2016 at Agricultural Research Institute, Dera Ismail Khan, Khyber Pakhtunkhwa, Pakistan. The aims of the study were to generate scientific information on nature and magnitude of genetic variability and relationship of yield and related attributes and to classify genotypes into distinct clusters on the basis of quantitative traits. Fourteen elite rice genotypes were evaluated following randomized complete block design with three replications. Analysis of variance manifested significant $(P \leq 0.01)$ differences among genotypes based on the studied traits viz., panicle emergence, flag leaf area, effective tillers plant ${ }^{-1}$, panicle length, primary branches and grains panicle ${ }^{-1}$, 10oo-grain weight and paddy yield plot ${ }^{-1}$, except physiological maturity. The magnitudes of PCV and GCV were higher (>20\%) in all the studied traits, except physiological maturity, reflecting wide spectrum of variability and offering greater opportunities for selection. Similarly, the magnitude of broad-sense heritability and genetic advance as percent of mean was moderate to high for majority of traits, indicating additive gene action in their inheritance hence, amenable for simple selection. Correlation analysis revealed that paddy yield manifested significantly positive correlation with physiological maturity $\left(r=0.46^{* *}\right)$ and negative correlation with 1000-grain weight $\left(r=-0.30^{*}\right)$. The dendrogram grouped 14 rice genotypes into four clusters. Cluster IV incorporated the highest number of genotypes, which also had highest cluster mean for paddy yield, followed by cluster I. Therefore, prominence should be given to genotypes aggregated in cluster I and IV that having high yield potentiality. Based on mean performance, Irrigated-04, E-93, E-94 and E-107 showed superiority in respect of paddy yield and some other traits, hence these lines could be recommended for varietal development.
\end{abstract}

Keywords: Correlation, Elite lines, Genetic variability

\section{INTRODUCTION}

After wheat, rice is the second most important crop in Pakistan, but lack of ample investment to improve varieties is one of the major factors that has delayed upsurge in paddy yield. However, to letdown this challenge and meet the growing demands, both classical and molecular breeding methods have to be used [1]. The need for prosper rice cultivation not only relies on cultural practices but also on their inbuilt genetic variability [2]. The existence of morpho-genetic variation in various yield attributes of rice is essential in determining best breeding procedures to enhance the paddy yield. A wide range of genetic variability for yield and its component attributes have been reported in the past [3]. Plant breeders systemically test and evaluate germplasm to generate best genetic stock, exploited for selection and production of high yielding cultivars.

Morphological attributes have been extensively used to ascertain polygenic relationships between and within species for studying variability and correlated characters in rice. However, morphological attributes are highly influenced by environmental factors, resulted in varying relationship patterns [4], nevertheless they are still effective for selection [5]. Qualitative and quantitative attributes have been used by many research scientists for different purposes in various crops including rice [6].

Paddy yield is the product of number of panicles per unit area, number of spikelets and filled grains panicle ${ }^{-1}$ and weight of thousand grains [7], therefore, breeding strategies in rice depends mainly on the extent and nature of variation of various yield attributes and their interrelationship. It is therefore important to assess extent

\section{Received o7 November 2017; Accepted 11 February 2018}

*Corresponding Author

Touheed Iqbal

Agricultural Research Institute, Dera Ismail Khan, Khyber Pakhtunkhwa, Pakistan

Email: touheed.ik@gmail.com

CThis article is open access and licensed under the terms of the Creative Commons Attribution License (http://creativecommons.org/licenses/by/4.o/) which permits unrestricted, use, distribution and reproduction in any medium, or format for any purpose, even commercially provided the work is properly cited. Attribution - You must give appropriate credit, provide a link to the license, and indicate if changes were made. 
of transmissibility and genetic gain of yield attributes to predict response to selection. A study of Bagati et al. [8] and Tejaswini et al. [9] revealed high heritability estimates for all the studied traits, while studies conducted by Bitew [10] on estimation of genetic parameters in upland rice assessed low heritability values for tillers plant ${ }^{-1}$, filled grains and seed yield. Correlation studies of paddy yield with other yield attributes not only envisage better insight towards the relationship among them [11] but also assists plant breeders in selection with more precision and accuracy [12]. The function of cluster analysis as a tool for classifying and grouping various genotypes with similar traits cannot be over-emphasized as it has now become popular among researchers [13]. Keeping in consideration, all the above information, an effort has been made in the present study to evaluate a set of 14 rice genotypes with an aim to assess genetic variability, heritability and genetic advance for yield and its component traits and unravel the degree of association between them and to classify 14 rice genotypes into groups based on their quantitative attributes.

\section{MATERIALS AND METHODS}

The current research was executed at Agricultural Research Institute, Dera Ismail Khan, Khyber Pakhtunkhwa, Pakistan during 2016 rice crop growing season. Fourteen selected rice genotypes were evaluated following randomized complete block design with three replications. Thirty days old nursery was transplanted into well puddled field with spacing of $20 \mathrm{~cm}$ each between rows and plants, respectively. Standard agronomic necessities were fulfilled to raise good crop. A composite of five plants were randomly selected in each $3 \times 4 \mathrm{~m}^{2}$ plot to record observations on flag leaf area, effective tillers plant ${ }^{-1}$, panicle length, filled grains panicle ${ }^{-1}$ and 1000-grain weight, while for days to panicle emergence and physiological maturity and paddy yield, data were recorded on plot basis. Finally, the mean values over three replications were used for statistical analysis and analysis was performed as per Steel et al. [14] and significant means were compared using LSD at $P \leq 0.05$. Phenotypic $\left(\sigma^{2} p\right)$ and genotypic $\left(\sigma^{2} g\right)$ variances were obtained according to Burton and DeVane [15] as $\sigma^{2} g=\mathrm{MS} p-(\mathrm{MSe} / r)$, $\sigma^{2} p=\mathrm{MS} g / r$ and $\sigma^{2} e=\mathrm{MS} e / r$, where $\mathrm{MS} p, \mathrm{MS} g$, MSe are mean squares of phenotypes, genotypes, error, respectively; $r$ was number of replications. Phenotypic coefficient of variation (PCV) and genotypic coefficient of variation (GCV) were assessed according to Burton [16] as PCV $(\%)=\left(\sigma^{2} p / \bar{x}\right) \times 10 O ; G C V(\%)=\left(\sigma^{2} g / \bar{x}\right) \times 10 O$, Where $\overline{\mathrm{x}}=$ grand mean of character under study. PCV and GCV values were characterized as low (0-10\%), moderate (10-20\%) and high (>20\%) according to Deshmukh et al. [17]. Broad Sense heritability $\left\{h^{2}(\mathrm{BS})\right\}$ for each trait was computed according to Falconer [18] as $h^{2}(\mathrm{BS})=\sigma^{2} g / \sigma^{2} p$. Heritability was characterized as low (0-30\%), moderate (>30-60\%) and high (>60\%) according to Robinson et al. [19]. Expected genetic advance (GA) was computed according to Allard [20] as GA $=\mathrm{k} \times \sigma^{2} p \times h^{2}(B S)$, where $\mathrm{k}$ is standardized selection differential constant (2.06) at $5 \%$ selection intensity. Genetic advance as percent of mean was assessed according to Comstock and Robinson [21] as GA $(\%)=($ genetic advance of particular trait $/ \overline{\mathrm{x}}) \times 100$. Genetic advance as percent of mean was characterize as low $(0-10 \%)$, moderate $(10-20 \%)$ and high $(>20 \%)$ as given by Johnson et al. [22]. Phenotypic correlation ( $r p$ ) was computed following the procedure of Kwon and Torrie [23] as $r p=\operatorname{COV}_{P\left(x_{1} x_{2}\right)} / \sqrt{\sigma^{2} P\left(x_{1}\right) \cdot \sigma^{2} P\left(x_{2}\right)}$
Where;

$\operatorname{COV}_{P(\mathrm{x} 1 \mathrm{x} 2)}=$ Phenotypic covariance among traits $\left(\mathrm{x}_{1}\right.$ and $\left.\mathrm{x}_{2}\right)$

$\sigma^{2} p\left(\mathrm{X}_{1}\right)=$ Phenotypic variance of trait $\mathrm{x}_{1}$

$\sigma_{p}^{2}\left(\mathrm{X}_{2}\right)=$ Phenotypic variance of trait $\mathrm{X}_{2}$

Grouping of genotypes into clusters was accomplished following the Ward's method [24].

\section{RESULTS AND DISCUSSION}

\section{Analysis of variance (ANOVA)}

Mean squares due to genotypes were significant $(P \leq 0.01)$ for panicle emergence, flag leaf area, effective tillers plant ${ }^{-1}$, panicle length, grains panicle ${ }^{-1}$, primary branches panicle ${ }^{-1}$, 1000-grain weight and paddy yield except physiological maturity (table 1). These results suggested that the studied genotypes had considerable variability for effective selection. A study conducted by Anis et al. [25] on 20 promising lines of rice under Egyptian condition found significant variations among genotypes for panicles plant ${ }^{-1}$, panicle length, number of grains panicle ${ }^{-1}$ and grain yield. Augustina et al. [2] also observed significant differences for all the traits while conducting studies on morphological characterization of 16 rice breeding lines. Similarly, other researchers [26-28] have also reported significant genetic differences in their studies conducted on evaluation of different rice genotypes.

It is obvious from table 2 that E-138 was the earliest in panicle emergence (113.00 days) and maturity (140.67 days). However, late maturity (153.33 days) was observed in E-93, Irrigated-03 and Irrigated-04. Flag leaf area is very important character, because it is responsible for transfer of assimilates to developing grains. Perusal of table 2 reveals that the maximum flag leaf area $\left(43.16 \mathrm{~cm}^{2}\right)$ was calculated for E-138, tailed closely by E-150 (42.45 $\mathrm{cm}^{2}$ ). Effective tillers plant ${ }^{-1}$ is also one of the important yield contributing traits, because panicle bearing tillers will obviously bring upsurge in the final yield. The current study revealed that mean values for effective tillers plant ${ }^{-1}$ ranged from 11.47 to 20.80. E-150 (20.80) and E-102 (20.00) produced utmost tillers plant ${ }^{-1}$. Minimum tillers plant $^{-1}$ (11.47) were produced by E-129. Panicle length is one of the most important traits assessed by rice breeders in yield related research, because longer panicles with more filled grains will obviously lead to higher return. Furthermore, research studies conducted previously [29-30] found that paddy yield is the product of number of panicles per unit area, percentage of filled grains panicle ${ }^{-1}$ and 1000-grain weight. Therefore, improvement in yield determining traits of cereals is of major concern of plant breeders. As depicted from table 2, mean values for panicle length ranged between 23.87 and $28.73 \mathrm{~cm}$. The longest panicles $(28.73 \mathrm{~cm})$ were produced by E-150, closely followed by E-102 and Irrigated-14 with panicle length of $28.26 \mathrm{~cm}$, respectively. Primary branches panicle ${ }^{-1}$ is also an important yield attribute, because panicles with maximum primary branches will obviously lead to higher grain yield. Primary branches panicle ${ }^{-1}$ ranged from 9.67 to 13.67 with an average value of 11.56. Irrigated-14 produced maximum (13.67) primary branches panicle ${ }^{-1}$, closely followed by E-107 (11.83), E-93 (11.33) and Irrigated-4 (11.33). Elite line 003 produced maximum (139.50) grains panicle $^{-1}$, while E-107 was second best line, producing 134.83 grains panicle ${ }^{-1}$. E-150 produced minimum primary branches (9.67) and grains panicle ${ }^{-1}$ (76.67). 1000-grain weight ranged from 18.70 to 26.37 g. Maximum 
1000-grain weight (26.27 g) was calculated for E-111, closely followed by Irrigated-01 $(26.24 \mathrm{~g})$ and E-102 (25.00 g). Development of high yielding rice cultivars with consistent performance is the real objective of rice breeders. The higher the grain yield plant ${ }^{-1}$, higher will be grain yield acre ${ }^{-1}$. On the basis of mean performance, Irrigated-04 (6.52 kg) and E-93 (6.36 kg) showed superiority in respect of grain yield plot ${ }^{-1}$, tailed closely by E-94 $(6.24 \mathrm{~kg})$ and E-107 $(6.15 \mathrm{~kg})$.

\section{Coefficients of variability}

Assessment of different genetic parameters have been presented in table 3 . The assessment of genetic variability revealed higher values $(>20 \%)$ for phenotypic coefficient of variation (PCV) for all the studied traits. Similarly, the magnitude of genotypic coefficient of variation (GCV) was also high $(>20 \%)$ for all the studied traits, except physiological maturity. The magnitude of PCV ranged from 27.96\% (panicle length) to $212.53 \%$ (grains panicle-1), while the magnitude of GCV ranged from $11.19 \%$ in physiological maturity to $179.64 \%$ in grains panicle ${ }^{-1}$ (table 3). The differences in PCV and GCV ranged from 1.04 to $55.26 \%$, indicating that genotypes had played an appreciative role rather than environment and indicating less influence of environment on these traits. It also suggested that selection based on these traits would be effective. Bagati et al. [8] evaluated $140 \quad \mathrm{~F}_{7}$ recombinant inbred lines (RILs) of rice and observed a wide range of phenotypic coefficient of variation $(6.1 \%-31.2 \%)$ and genotypic coefficient of variation (5.7\%-30.5\%) for the studied traits. Similarly, Prasad et al. [31] evaluated 50 boro-rice genotypes and reported that the magnitude of PCV and GCV was moderate ( $>10 \%)$ to high $(>20 \%)$ for most of the traits including grain yield. Another study conducted by Manikya and Reddy [32] reported less differences between PCV and GCV values for all the traits and concluded that there was less influence of environment on the expression of these traits.

\section{Heritability and genetic advance}

Knowledge of the extent of transmissibility of a particular trait assists plant breeders in predicting the behavior of succeeding generations because higher heritability of a trait simplifies the selection procedure [33]. Studied conducted previously by several researchers [34-38] have emphasized the utility of assessment of heritability and genetic advance in the anticipation of response of quantitative traits to selection. Genotypic variances were higher than corresponding environmental variances for all the studied traits, resulting in high heritability for most of the traits. Estehghari and Farshadfar [39] stated that higher the genetic variance, more are the chances of bringing sustainable improvement through selection. The magnitude of broad-sense heritability ranged from $2.84 \%$ (physiological maturity) to $98.50 \%$ (1000-grain weight), while corresponding values of genetic advance ranged from $0.32 \%$ (physiological maturity) to $59.49 \%$ (1000-grain weight) (table 3 ). The highest heritability $(>60 \%)$ coupled with high genetic advance $(>20 \%)$ was assessed for grains panicle ${ }^{-1}(71.44 \%, 30.65 \%)$ and 1000 -grain weight $(98.50 \%, 59.49 \%)$ which is in line with the findings of Tuhina-Khatun et al. [40] for grains panicle $^{-1}$ and Nirmaladevi et al. [3] for 1000-grain weight. Traits with high heritability and genetic advance could be explained by additive gene action and have high response to selection. So importance should be given to these traits in selection breeding. Whereas, traits exhibiting low genetic advance accompanied by moderate to high heritability indicate the non-additive gene action, thus selection should be practiced with care in respect of low heritable traits. In this regard, further explanation of Sardana et al. [41] suggested that traits with high heritability might not necessarily lead to higher genetic advance. High heritability $(>60 \%)$ and moderate genetic advance $(>10-20 \%)$ was assessed for primary branches panicle $^{-1}$, while traits such as panicle emergence and panicle length manifested high heritability ( $>60 \%$ ) and low genetic advance (0-10\%). Moderate heritability with high genetic advance was assessed for flag leaf area (51.99\%, $21.84 \%$ ) and paddy yield (51.67\%, 27.37\%). Moderate heritability coupled with high genetic advance for paddy yield have been reported earlier in the literature [42], which support the present findings. Tillers plant ${ }^{-1}$ manifested moderate heritability (39.80\%) with moderate genetic advance (16.28\%) which is in line with findings of Konate et al. [26]. Low heritability (2.84\%) coupled with low genetic advance (0.32\%) was assessed for physiological maturity, indicating ineffectiveness of direct selection. Kumar and Deo [43] reported moderate to high heritability coupled with low genetic advance (\%) for days to maturity and panicle length.

\section{Phenotypic correlation}

As yield is a polygenic trait, so assessment of correlation among yield and component traits is necessary to identify such characters with significant effect on paddy yield and elimination of those with undesirable correlative changes. In the present study, assessment of correlation revealed that days to panicle emergence $(r=-0.48, P \leq 0.01)$ and physiological maturity $(r=-0.33, P \leq 0.05)$ was found to be negatively correlated with flag leaf area. Grains panicle ${ }^{-1}$ was positively correlated with panicle emergence $(r=0.56$, $P \leq 0.01)$ and primary branches panicle ${ }^{-1}(\mathrm{r}=0.54, P \leq 0.01)$, but negatively correlated to effective tillers plant ${ }^{-1}(r=-0.35$, $P \leq 0.05)$. Paddy yield manifested positive correlation with physiological maturity $(r=0.46, P \leq 0.01)$, while negative correlation with 1000 -grain weight $(r=-0.30, P \leq 0.05)$. The remaining traits manifested no correlation with paddy yield (table 4). Some early literature [44-46] reported significantly positive correlation of paddy yield with effective tillers plant ${ }^{-1}$, panicle length, grains panicle ${ }^{-1}$ and 1000-grain weight, which do not support the present findings.

\section{Cluster analysis}

Among 14 elite rice genotypes, cluster analysis resulted in four clusters following Ward's method (fig. 1). Distribution pattern indicated that maximum genotypes (05) were aggregated in cluster IV, while minimum (02) were grouped into cluster II. Cluster I and III comprised 03 and 04 genotypes respectively (table 5). Cluster wise mean values of nine different traits were computed to assess superiority of cluster, which could be considered in the improvement of various characters [47]. Mean performance of different clusters for the characters manifested that genotypes with maximum days to physiological maturity, panicle length, primary branches panicle ${ }^{-1}$ and 1000-grain weight was accumulated in cluster I, whereas genotypes with maximum paddy yield were in grouped cluster IV. Similarly, genotypes which took minimum days to panicle emergence and physiological maturity and produced maximum flag leaf area and effective tillers plant ${ }^{-1}$ were clubbed into cluster III, whereas low yielding genotypes with minimum effective tillers plant ${ }^{-1}$ and 1000 -grain weight were grouped into cluster II (table 6). 


\section{CONCLUSION}

On the basis of summarized results as above, the present study identified the presence of adequate genetic variability in the tested genotypes. The magnitude of heritability and genetic advance was moderate to high for most of the traits, offering more space and opportunity for improvement. Paddy yield manifested significantly positive correlation with physiological maturity while significantly negative correlation with 1000 -grain weight. A group of genotypes in cluster I and IV was identified as being different from other for number of traits including paddy yield. Similarly, on the basis of mean performance, Irrigated-04, E-93, E-94 and E-107 were identified as the most prominent genotypes. Therefore, these genotypes may be good for rice improvement programs.

Table 1: Mean squares for various traits of 14 elite genotypes of rice

\begin{tabular}{lllll}
\hline Traits & $\begin{array}{l}\text { Replications } \\
(\boldsymbol{d} \boldsymbol{f}=\mathbf{2})\end{array}$ & $\begin{array}{l}\text { Genotypes } \\
(\boldsymbol{d} \boldsymbol{f}=\mathbf{1 3})\end{array}$ & $\begin{array}{l}\text { Error } \\
(\boldsymbol{d} \boldsymbol{f}=\mathbf{2 6})\end{array}$ & CV (\%) \\
\hline Panicle emergence & 6.16 & $119.07^{* *}$ & $5 \cdot 52$ & 1.93 \\
Flag leaf area & 19.91 & $102.61^{* *}$ & 24.15 & 14.13 \\
Physiological maturity & 4.02 & $69.40^{\text {NS }}$ & 63.18 & 5.37 \\
Effective tillers plant $^{-1}$ & 16.73 & $20.42^{* *}$ & 6.84 & 15.4 \\
Panicle length $_{\text {Primary branches panicle-1 }}^{-1}$ & 0.75 & $4.70^{* *}$ & 0.82 & 3.35 \\
Grains panicle $^{-1}$ & 0.07 & $3.58^{* *}$ & 0.46 & 5.84 \\
1OOO-grain weight $_{\text {Paddy yield plot }^{-1}}^{122.93}$ & $\mathbf{1 1 4 2 . 8 1 ^ { * * }}$ & 134.38 & 11.13 \\
\hline
\end{tabular}

**= significant at $1 \%$ level of probability, $\mathrm{NS}=$ non-significant

Table 2: Mean values for various traits of 14 elite genotypes of rice

\begin{tabular}{|c|c|c|c|c|c|c|c|c|c|}
\hline Genotypes & $\begin{array}{c}\text { PE } \\
\text { (days) }\end{array}$ & $\begin{array}{c}\text { FLA } \\
\left(\mathrm{cm}^{2}\right)\end{array}$ & $\begin{array}{c}\text { PM } \\
\text { (days) }\end{array}$ & $\begin{array}{c}\text { ET } \\
\text { (no.) }\end{array}$ & $\begin{array}{c}\text { PL } \\
(\mathrm{cm})\end{array}$ & $\begin{array}{c}\text { PBP } \\
\text { (no.) }\end{array}$ & $\begin{array}{c}\text { GP } \\
\text { (no.) }\end{array}$ & $\begin{array}{c}\text { TGW } \\
\text { (g) }\end{array}$ & $\begin{array}{c}\text { PY } \\
\text { (kg) }\end{array}$ \\
\hline E-93 & 119.00 & 35.00 & 154.33 & 16.67 & 26.69 & 11.33 & 100.50 & 23.17 & 6.36 \\
\hline E-94 & 126.33 & 29.91 & 149.33 & 18.87 & 26.32 & 11.50 & 87.00 & $24 \cdot 37$ & 6.24 \\
\hline E-102 & 123.33 & 24.85 & 150.67 & 20.00 & 28.26 & 10.83 & 111.33 & 25.00 & 4.67 \\
\hline E-107 & 130.00 & 25.44 & 152.00 & 13.13 & 27.51 & 11.83 & 134.83 & 18.70 & 6.15 \\
\hline E-111 & 124.67 & 27.34 & 153.67 & 15.67 & 27.75 & $11.5^{0}$ & 107.50 & 26.37 & 5.26 \\
\hline E-116 & 123.00 & 37.25 & 152.00 & 15.27 & 25.77 & 13.50 & 121.17 & 24.47 & 5.11 \\
\hline E-127 & $113 \cdot 33$ & 39.66 & 143.33 & 17.93 & 23.87 & 10.83 & 83.67 & 24.10 & 4.48 \\
\hline E-129 & 116.33 & 36.09 & 141.67 & 11.47 & 26.30 & 12.00 & 84.17 & 23.67 & 3.97 \\
\hline E-138 & 113.00 & 43.16 & 140.67 & 19.20 & 27.30 & 12.17 & 100.67 & 23.70 & 4.47 \\
\hline E-150 & $113 \cdot 33$ & 42.45 & 143.67 & 20.80 & 28.73 & 9.67 & 76.67 & 23.87 & 5.43 \\
\hline 003 & 130.33 & 38.47 & 146.00 & 15.57 & 26.69 & 11.50 & 139.50 & $23 \cdot 31$ & 2.63 \\
\hline Irrigated-3 & 131.00 & 34.67 & $153 \cdot 33$ & 16.77 & 27.75 & 10.17 & 89.00 & 26.24 & $5 \cdot 54$ \\
\hline Irrigated-4 & 122.33 & 36.76 & $153 \cdot 33$ & 17.87 & 27.51 & 11.33 & 101.50 & 19.72 & 6.52 \\
\hline Irrigated-14 & 122.67 & 35.94 & 148.67 & 18.60 & 28.26 & 13.67 & 120.83 & 24.50 & 5.00 \\
\hline Mean & 122.05 & 34.79 & 148.76 & 16.99 & 27.05 & 11.56 & 104.17 & 22.08 & 5.05 \\
\hline LSD (0.05) & 3.93 & 8.22 & NS & $4 \cdot 38$ & 1.52 & 1.13 & 19.39 & 1.33 & 1.51 \\
\hline
\end{tabular}

Note: PE-panicle emergence, FLA-flag leaf area, PM-physiological maturity, ET-effective tillers plant ${ }^{-1}$, PL-panicle length, PBP-primary branches panicle ${ }^{-1}$, GP-grains panicle ${ }^{-1}$, TGW-1000-grain weight and PY-paddy yield plot ${ }^{-1}$.

Table 3: Assessment of genetic parameters for various traits of 14 elite genotypes of rice

\begin{tabular}{|c|c|c|c|c|c|c|c|c|}
\hline Traits & PCV & GCV & PCV-GCV & $\sigma^{2} g$ & $\sigma^{2} p$ & $h^{2}(\mathrm{BS})$ & GA & GA (\%) \\
\hline Panicle emergence & 59.61 & 55.69 & 3.93 & 37.85 & $43 \cdot 37$ & 87.26 & 11.84 & 9.70 \\
\hline Flag leaf area & 120.26 & 86.72 & 33.54 & 26.16 & 50.31 & 51.99 & 7.60 & 21.84 \\
\hline Physiological maturity & 66.45 & 11.19 & 55.26 & 1.86 & 65.68 & 2.84 & 0.47 & 0.32 \\
\hline Effective tillers plant ${ }^{-1}$ & 81.83 & 51.62 & 30.21 & 4.53 & 11.37 & 39.80 & 2.76 & 16.28 \\
\hline Panicle length & 27.96 & 21.87 & 6.09 & 1.29 & 2.11 & 61.17 & 1.83 & 6.77 \\
\hline Primary branches panicle ${ }^{-1}$ & 36.01 & 30.04 & 5.97 & 1.04 & 1.50 & 69.60 & 1.76 & 15.18 \\
\hline Grains panicle $^{-1}$ & 212.53 & 179.64 & 32.90 & 336.14 & 470.52 & 71.44 & 31.92 & 30.65 \\
\hline 1000-grain weight & 137.75 & 136.71 & 1.04 & 41.26 & 41.89 & 98.50 & 13.13 & 59.49 \\
\hline Paddy yield plot ${ }^{-1}$ & 57.80 & 41.54 & 16.25 & 0.87 & 1.69 & 51.67 & 1.38 & 27.37 \\
\hline
\end{tabular}

Note: GCV= genotypic coefficient of variance, $\mathrm{PCV}=$ phenotypic coefficient of variance, $\sigma^{2} g=$ genetic variance, $\sigma^{2} p=$ phenotypic variance, $h^{2}(\mathrm{BS})=$ broad-sense heritability, GA $(\%)=$ genetic advance as percent of mean 
Table 4: Correlation coefficients of paddy yield with component traits

\begin{tabular}{|c|c|c|c|c|c|c|c|c|}
\hline & FLA & $\mathbf{P M}$ & ET & $\mathbf{P L}$ & PBP & GP & TGW & PY \\
\hline PE & $-0.48^{* *}$ & 0.29 & -0.23 & 0.18 & 0.09 & $0.56^{* *}$ & -0.07 & 0.09 \\
\hline FLA & & $-0.33^{*}$ & 0.11 & -0.19 & -0.06 & -0.22 & 0.04 & -0.22 \\
\hline PM & & & -0.01 & 0.23 & -0.08 & 0.11 & -0.04 & $0.46^{* *}$ \\
\hline ET & & & & 0.28 & -0.25 & $-0.35^{*}$ & 0.21 & 0.09 \\
\hline PL & & & & & -0.17 & 0.07 & 0.02 & 0.08 \\
\hline PBP & & & & & & $0.54^{* *}$ & -0.06 & -0.17 \\
\hline GP & & & & & & & -0.25 & -0.18 \\
\hline TGW & & & & & & & & $-0.30^{*}$ \\
\hline
\end{tabular}

${ }^{* *},{ }^{*}=$ significant at $1 \%$ and $5 \%$ level of probability, respectively,

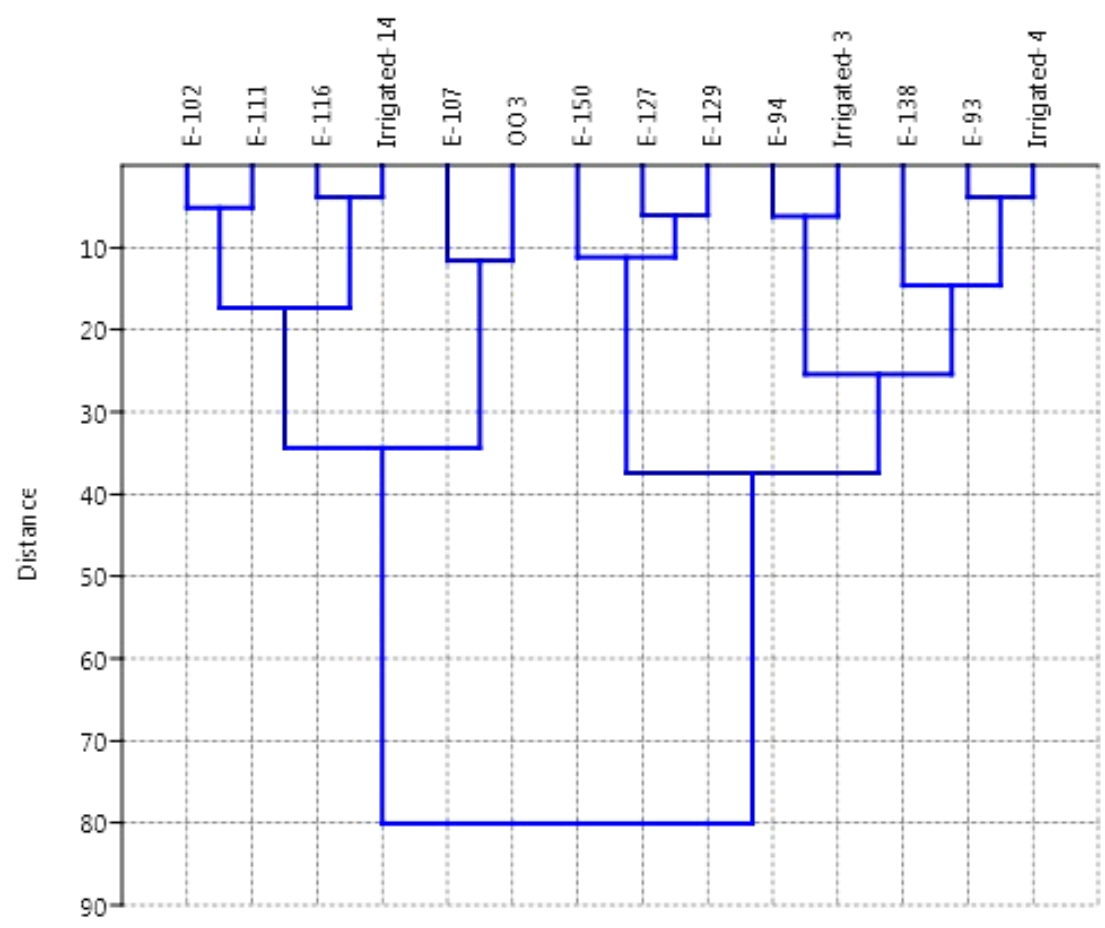

Fig. 1: Dendrogram of 14 elite rice genotypes using Ward`s method

Table 5: Grouping of 14 elite rice genotypes by Ward's method

\begin{tabular}{lcl}
\hline Cluster & Number of genotypes & Name of genotypes \\
\hline I & 4 & E-102, E-111, E-116, Irrigated-14 \\
II & 2 & E-107, O03 \\
III & 3 & E-150, E-127, E-129 \\
IV & 5 & E-93, E-94, E-138, Irrigated-3, Irrigated-4 \\
\hline
\end{tabular}

Table 6: Cluster mean for nine characters of 14 elite rice genotypes

\begin{tabular}{|c|c|c|c|c|}
\hline \multirow{2}{*}{ Traits } & \multicolumn{4}{|c|}{ Cluster means } \\
\hline & Cluster-I & Cluster-II & Cluster-III & Cluster-IV \\
\hline Panicle emergence & 123.42 & 130.17 & 113.33 & 122.33 \\
\hline Flag leaf area & 31.34 & 31.96 & 41.06 & 35.90 \\
\hline Physiological maturity & 151.25 & 149.00 & 143.50 & 150.20 \\
\hline Effective tillers plant ${ }^{-1}$ & 17.38 & 14.35 & 19.37 & 17.87 \\
\hline Panicle length & 27.51 & 27.10 & 26.30 & 27.11 \\
\hline Primary branches panicle ${ }^{-1}$ & 12.38 & 11.67 & 10.25 & 11.30 \\
\hline Grains panicle $^{-1}$ & 115.21 & 137.17 & 80.17 & 95.73 \\
\hline 1000-grain weight & 25.08 & 21.00 & 23.98 & 23.44 \\
\hline Paddy yield plot ${ }^{-1}$ & 5.01 & 4.39 & 4.96 & 5.82 \\
\hline
\end{tabular}




\section{REFERENCES}

1. Smith CW, Dilday RH. Rice: Origin, history, technology, and production, $1^{\text {st }}$ ed. John Wiley and Sons, Inc., Hoboken, New Jersey. 2003.

2. Augustina UA, Iwunor OP, Ijeoma OR. Heritability and character correlation among some rice genotypes for yield and yield components. J. Plant Breed. Genet. 2013;1:73-84.

3. Nirmaladevi G, Padmavathi G, Kota S, Babu VR. Genetic variability, heritability and correlation coefficients of grain quality characters in rice (Oryza sativa L.). SABRAO J. Breed. Genet. 2015;47: 424-433.

4. Selvi R, Muthiah AR, Maheswaran M, Shanmugasundaram. Genetic diversity in the genus Vigna based on morphological traits and isozyme markers. SABRAO J. Breed. Genet. 2003;35:103-112.

5. Megloire N. The genetic, morphological and physiological evaluation of African cowpea genotypes. University of Free State. 2005.

6. Obute GC. The morphological characterization of an aneuploid Vigna unguiculata (L.). Walp Nigr. J. Genet. Breed. 2001;55:307-311.

7. De Datta SK. Principles and practices of Rice production. John Wiley and sons New York. 1981;p618.

8. Bagati S, Singh AK, Salgotra RK, Bhardwaj R, Sharma M, Rai SK, Bhat A. Genetic variability, heritability and correlation coefficients of yield and its component traits in basmati rice. SABRAO J. Breed. Genet. 2016;48:445-452.

9. Tejaswini KLY, Kumar R, Mohammad LA, Raju SK, Srinivas M, Rao PVR. Study of genetic parameters in $\mathrm{F}_{5}$ families of rice (Oryza sativa L.). Int. J. Environ. Agric. Biotechnol. 2016;1:735-738.

10. Bitew JM. Estimation of genetic parameters, heritability and genetic advance for yield related traits in upland rice (Oryza sativa L. and Oryza glaberrima Steud) genotypes in northwestern Ethiopia. WSN. 2016;47:340-350.

11. Jayasudha S, Sharma D. Genetic parameters of variability, correlation and path-coefficient for grain yield and physiological traits in rice (Oryza sativa L.) under shallow lowland situation. Electronic J. Plant Breed. 2010;1:1332-1338.

12. Ratna M, Begum S, Husna A, Dey SR, Hossain MS. Correlation and path coefficients analyses in basmati rice. Bangladesh J. Agril. Res. 2015;40:153-161.

13. Vural H, Karasu A. Variability studies in cowpea (Vigna unguiculata L. Walp.) varieties grown in Isparta, Turkey. Revista UDO Agricola, 2007;7:29-34.

14. Steel RGD, Torrie JH, Dickey DA. Principles and Procedures of Statistics: A Biometric Approach ( $3^{\text {rd }}$ Ed.) McGraw-Hill Book Co., New York. USA. 1997.

15. Burton GW, DeVane EM. Estimating heritability in tall fescue (Festuca arundinacea) from replicated clonal material. Agron. J. 1953;45:478-481.

16. Burton GW. Quantitative inheritance in grasses proceedings of $6^{\text {th }}$ Grassland congress J. 1952;1:277-281.

17. Deshmukh SN, Basu MS, Reddi PS. Genetic variability, character association and path coefficient of quantitative traits in Virginia bunch varieties of groundnut. Indian J. Agric. 1986;56:816-821.

18. Falconer DS. Introduction to quantitative genetics $\left(3^{\text {rd }}\right)$. Longman Scientific and Technical, Longman House, Burnt Mill, Harlow, Essex, England. 1989.
19. Robinson HF, Comstock RE, Harvey PH. Estimates of heritability and the degree of dominance in corn. Agron. J. 1949;42:353-359.

20. Allard RW. Principles of Plant Breeding. John Wiley and Sons, New York. 1960.

21. Comstock RE, Robinson HF. Genetic parameters, their estimation and significance. Proc. $6^{\text {th }}$ Intl. Grassland Cong. 1952;1:284-291.

22. Johnson HW, Robinson HF, Comstock RE. Estimates of genetic and environmental variability in soybean. Agron. J. 1955;47:314-318.

23. Kwon SH, Torrie JH. Heritability and interrelationship of traits of two soybean populations. Crop Sci. 1964;4:196-198.

24. Ward JH. Hierarchical grouping to optimize an objective function. J. Am. Stat. Assoc. 1963;58:236-244.

25. Anis G, El-sabagh A, Ghareb A, El-Rewainy I. Evaluation of promising lines in rice (Oryza sativa L.) to agronomic and genetic performance under Egyptian condition. Int. J. Agron. Agric. Res. 2016;8:52-57.

26. Konate AK, Zongo A, Kam H, Sanni A, Audebert A. Genetic variability and correlation analysis of rice (Oryza sativa L.) inbred lines based on agro-morphological traits. Afr. J. Agric. Res. 2016;11:3340-3346.

27. Pradhan, B., T. K. Mishra and S. R. Das. 2015. Genetic basis of yield variations in Lowland rice. Int. J. Basic and App. Sci. 19: 306-318.

28. Akhtar N, Nazir MF, Rabnawaz A, Mahmood T, Safdar ME, Asif M, Rehman A. Estimation of heritability, correlation and path coefficient analysis in fine grain rice (Oryza sativa L.) J. Anim. Plant Sci. 2011;21:660-664.

29. Samonte SO, Wilson LT, McClung AM. Path analysis of yield and yield-related traits of fifteen diverse rice genotypes. Crop Sci. 1998;38:1130-1136.

3o. Mehetre SS, Mahajan CR, Patil PA, Lad SK, Dhumal PM. Variability, heritability, correlation, path analysis, and genetic divergence studies in upland rice. IRRN. 1994;19:8-9.

31. Prasad KR, Radha-Krishna KV, Bhave MHV, Subba-Rao LV. Genetic variability, heritability and genetic advance in boro rice (Oryza sativa L.) germplasm. Int. J. Curr. Microbiol. App. Sci. 2017;6:1261-1266.

32. Manikya CM, Reddy TD. Studies on genetic divergence in medium duration elite rice genotypes (Orzya sativa L.). J. Res. ANGRAU, 2011;39:122.

33. Khaliq I, Noorka LR, Khaliq R. Estimation of heritability and genetic advance for some quantitative characters in spring wheat. Int. J. Agric. App. Sci. 2009;1:76-78.

34. Sumanth V, Suresh BG, Ram BJ, Srujana G. J. Pharmacog. Phytochem. 2016;6:1437-1439.

35. Rukmini KD, Parimala K, Venkanna V, Lingaiah N, Hari Y, Chandra BS. Estimation of variability for grain yield and quality traits in rice (Oryza sativa L.). Int. J. Pure App. Biosci. 2016;4:250-255.

36. Ogunbayo SA, Sié M, Ojo DK, Sanni KA, Akinwale MG, Toulou B, Shittu A, Idehen EO, Popoola AR, Daniel IO, Gregoria GB. Genetic variation and heritability of yield and related traits in promising rice genotypes (Oryza sativa L.). J. Plant Breed. Crop Sci. 2014;6:153-159.

37. Bornare SS, Mittra SK, Mehta AK. Genetic variability, correlation and path analysis of floral, yield and its component traits in $\mathrm{cms}$ and restorer lines of rice (Oryza sativa L.). Bangladesh J. Bot. 2014;43: 45-52. 
38. Paikhomba N, Kumar A, Chaurasia AK, Rai PK. Assessment of genetic parameters for yield and yield components in hybrid Rice and parents. J. Rice Res. 2014;2:117.

39. Estehghari MR, Farshadfar E. Evaluation of phenotypic variability, genetic parameters, heritability and genetic gain in bread wheat genotypes under rainfed conditions. Int. J. Biosci. 2015;4:193-201.

40. Tuhina-Khatun M, Hanafi MM, Yusof MR, Wong MY, Salleh FM, Ferdous J. Genetic variation, heritability, and diversity analysis of upland rice (Oryza sativa L.) genotypes based on quantitative traits. Biomed. Res. Int. ID 290861, 2015

41. Sardana S, Mahajan RK, Gautam NK, Ram B. Genetic variability in pea (Pisum sativum L.) germplasm for utilization. SABRAO J. Breed. Genet. 2007;39:31-41.

42. Abebe T, Alamerew S. Tulu L. Genetic variability, heritability and genetic advance for yield and its related traits in rainfed lowland rice (Oryza sativa L.) genotypes at Fogera and Pawe, Ethiopia. Adv. Crop. Sci. Tech. 2017;5:272-279.
43. Kumar S, Deo I. Studies on genetic variability, heritability and genetic advance in advance lines of Kalanamak aromatic rice (Oryza sativa L.). Eco. Env. Cons. 2016;22: 891-895.

44. Osundare OT, Akinyele BO, Fayeun LS, Osekita OS. Evaluation of qualitative and quantitative traits and correlation coefficient analysis of six upland rice varieties. J. Biotechnol. Bioeng. 2017;1:17-27.

45. Kalyan B, Radha Krishna KV, Subba Rao LV. Correlation coefficient analysis for yield and its components in rice (Oryza sativa L.) genotypes. Int. J. Curr. Microbiol. App. Sci. 2017;6:2425-2430.

46. Akhter MS, Rizwan M, Akhter M, Naeem M, Hussain W, Elahi F, Latif M. Genotypic and phenotypic condition coefficient analysis for yield and yield related components in basmati rice (Oryza sativa L.). Am-Euras. J. Agric. Environ. Sci. 2014;14:1402-1404.

47. Ahmed A, Shaon SG, Islam MS, Saha PS, Islam MM. Genetic divergence analysis in HRDC rice (Oryza sativa L.) hybrids in Bangladesh. Bangladesh J. Pl. Breed. Genet. 2014;27: 25-32. 